\title{
CONCRETE CANOE: A COMPLEX CONCRETE TECHNOLOGY
}

\author{
Péter Leczovics ${ }^{1}$, Viktória Sugár ${ }^{2}$ \\ ${ }^{1}$ Institute of Construction Management, Szent István University, Budapest, Hungary \\ Leczovics.Peter@ybl.szie.hu \\ ${ }^{2}$ Institute of Construction Management, Szent István University, Budapest, Hungary \\ Sugar.Viktoria@ybl.szie.hu
}

\begin{abstract}
The Concrete Canoe Competition has been organized second time in Hungary in 2013. The main point of the competition is to design and create a floating concrete object with specified dimensions, which does not contain statically rigid frame. A speed-trial is also part of the contest.

The team of Szent István University, Ybl Miklós Faculty of Architecture and Civil Engineering attended both the first (2012) and the second (2013) competition. In both years the main part of designing and creation of the canoe was under the direction of employees of Building Materials division of the Insitute.

Building a concrete canoe proved to be a complex challenge. Knowledge of different engineering fields was required to solve the task - questions about material properties, hydrodynamics, statics, technologies were needed to be solved.

Present paper introduces the authors' experience, investigations, and means of realization of the concrete canoe.
\end{abstract}

Keywords: lightweight concrete, expanded glass aggregate

\section{INTRODUCTION [1,2]}

As a matter of curiosity, the idea of ships and boats made of concrete is in close connection with the invention of reinforced concrete. A French gardener, J. Monier (1823-1906) invented the steel reinforced concrete in 1849, but it was not patented until 1867 named a „,movable flowerpot and container made of cement for gardening purposes". This invention started the development of reinforced concrete and structures made from the material (pipes, containers, bridges, etc.).

The first boat made of reinforced concrete was built by a French farmer, J.L. Lambot (1814-1887), and it was presented during the World Fair in Paris, 1885.

This technological innovation was noticed by the navy, however later the idea of reinforced concrete warships was rejected, because they proved to be heavy, less easily manoeuvrable, and damageable.

Nevertheless a few ships were built by using this technology. 
Floating object made of (reinforced) concrete came to the fore again with the development of concrete technology

(lightweight concrete, admixtures, fibres, polymers, etc.).

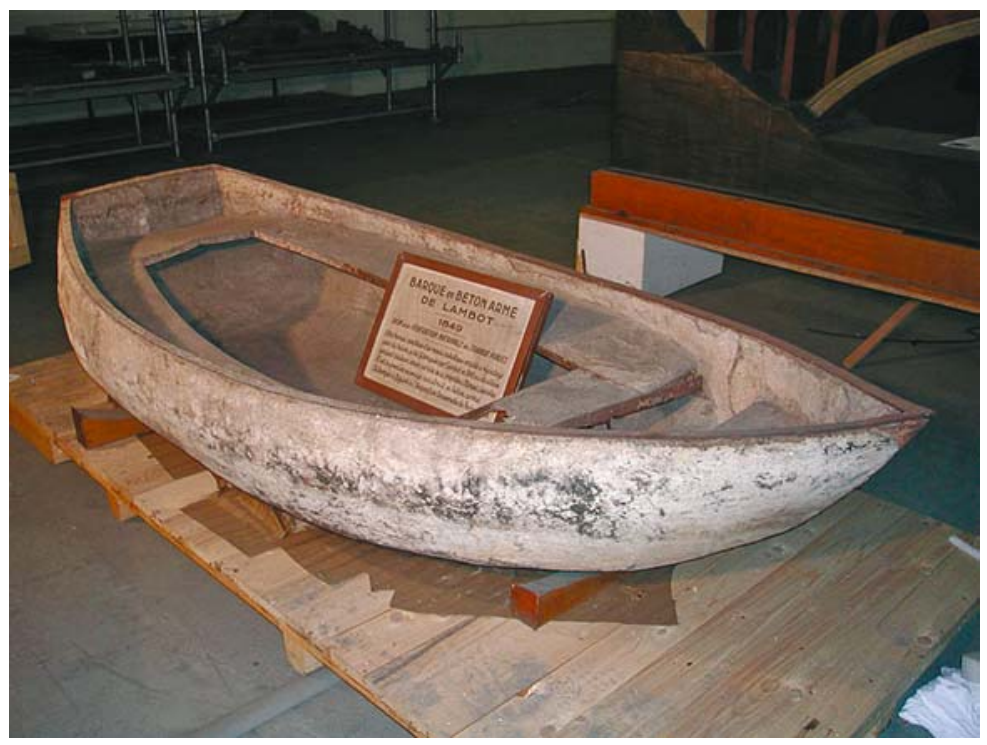

Figure 1. Joseph-Louis Lambot's boat made of reinforced conrete in 1855 [3]

Concrete canoe competitions have surprisingly long traditions abroad, mainly in the United States of America and Canada. First competitions were organized in the 1960-s between universities, and became a national competition later, in 1988. The yearly competitions are organized by the association of American engineers for the purpose of giving opportunity to university students to try their theoretic studies in practice. On these north-american events mainly universities compete with each other. Later, these competitions were organized in other continents too, also in Europe, for example in Germany.

\section{PRELIMINARY EXPECTATIONS}

In consideration of not having experience in this "special" field of engineering, the authors began working by two main viewpoint: surveying research papers of the topic, and creating a list of requirements that the concrete canoe itself and the material it is made of should meet. By processing data of papers and foreign competitions the authors created a requirement list which contains two main topics:

1.) Requirements of mix:

a.) The fresh concrete should be homogeneous and easily workable.

b.) The hardened concrete should be lightweight, watertight, be mostly void of shrinkage cracks, possessing considerable compressive-, tensile-, and flexible strength. 
2.) Requirements of technology:

a.) Position of formwork

b.) Material of formwork

b.) Method of building - aesthetic surface

\section{CHOICE OF MATERIALS}

During preliminary survey and various investigations it was made clear that lightweight concrete should be used. Lightweight concretes are either created by using lighter aggregates or using additives and admixtures for creating porous material (for example: alumina powder). Either way, if bulk density is under $2000 \mathrm{~kg} / \mathrm{m}^{3}$, the concrete can be considered lightweight. [6]. Lightweight concretes can be sorted by different viewpoints, for example by the required properties, (Figure 2., Table 1.), or by method of creating the pores (Figure 3.).

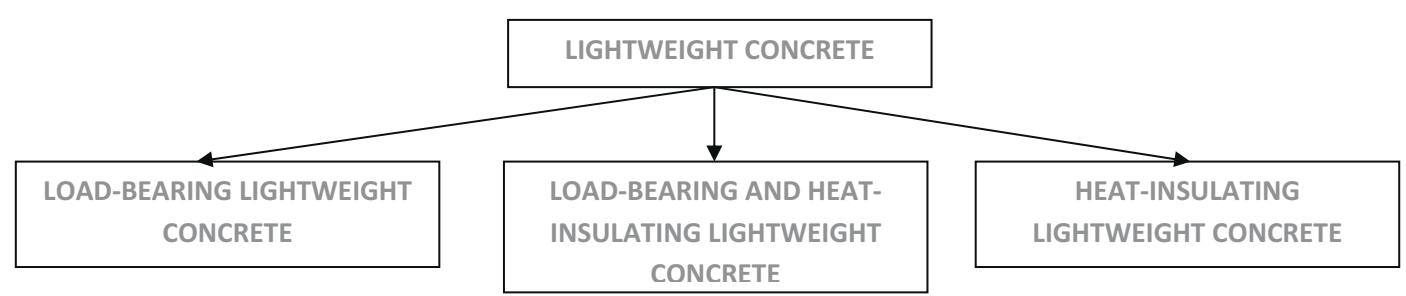

Figure 2. Sorting of lightweight concretes by the requirements and properties [7]

\begin{tabular}{|c|c|c|c|}
\hline $\begin{array}{c}\text { Name of } \\
\text { concrete }\end{array}$ & $\begin{array}{c}\text { Average } \\
\text { compressive } \\
\text { strength } \\
\mathbf{M P a}\end{array}$ & $\begin{array}{c}\text { Bulk density } \\
\mathbf{~ k g} / \mathbf{m}^{3}\end{array}$ & $\begin{array}{c}\text { Thermal } \\
\text { conductivity } \\
\mathbf{W} / \mathbf{m K}\end{array}$ \\
\hline $\begin{array}{c}\text { Thermal- } \\
\text { insulating } \\
\text { lightweight } \\
\text { concrete }\end{array}$ & 3,5 & $<800$ & $<0,29$ \\
\hline $\begin{array}{c}\text { Thermal - } \\
\text { insulating, load- } \\
\text { bearing } \\
\text { lightweight } \\
\text { concrete }\end{array}$ & 14 & $<1.000$ & $0,29-0,75$ \\
\hline $\begin{array}{c}\text { Load-bearing } \\
\text { lightweight } \\
\text { concrete }\end{array}$ & $>14$ & $<1.900$ & \\
\hline
\end{tabular}

Table 1. Sorting of lightweight concretes by the requirements and properties [8] 


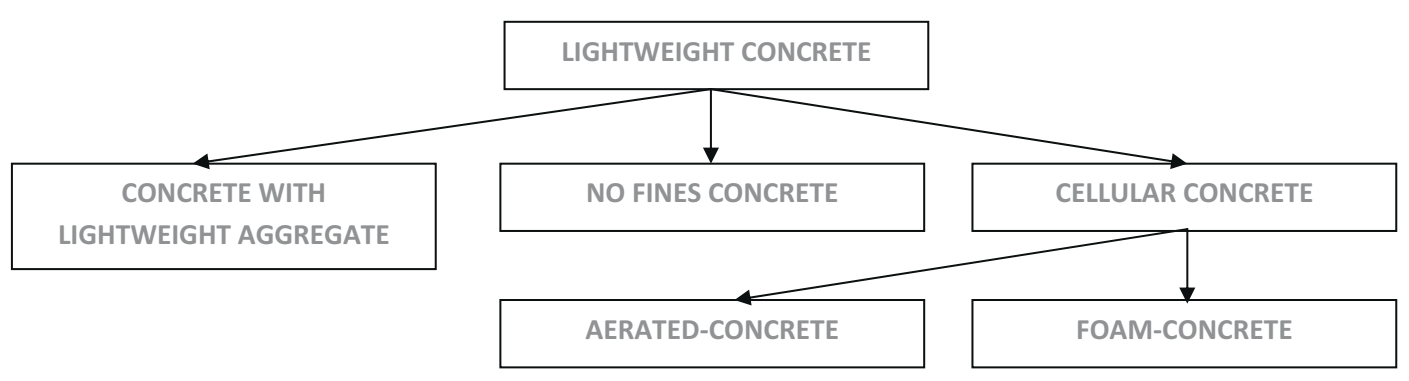

Figure 3. Sorting of lightweight concrete by method of creating pores [7]

\subsection{Lightweight aggregates}

Lightweight aggregates also can be sorted into different groups (for example by bulk density, type of origin and manufacturing).

Through preliminary hydrotechnical investigations the authors concluded that the hydration of used aggregates should be minimal - for this reason the natural lightweight aggregates (vulcanic tufa, perlite...) were ruled out, because of the high hydration rate: 10-30\% [9].

From the artificial section of lightweight aggregates the dross, bat, expanded clay and polystyrene were also ruled out for same reasons.

Out of the remaining options the authors chose the expanded glass, which is distributed by a German company as PORAVER in Hungary.

\subsection{Expanded glass granule [7]}

The granule is basically manufactured from selectively collected and recycled glass garbage and waste. Besides environment-friendly, the product has many advantages, from which the most important features are the following: low body and agglomerate density, high compression strength, minimal hydration, UV and biological pest resistant. The most important properties of the expanded glass are shown in the Table 2.

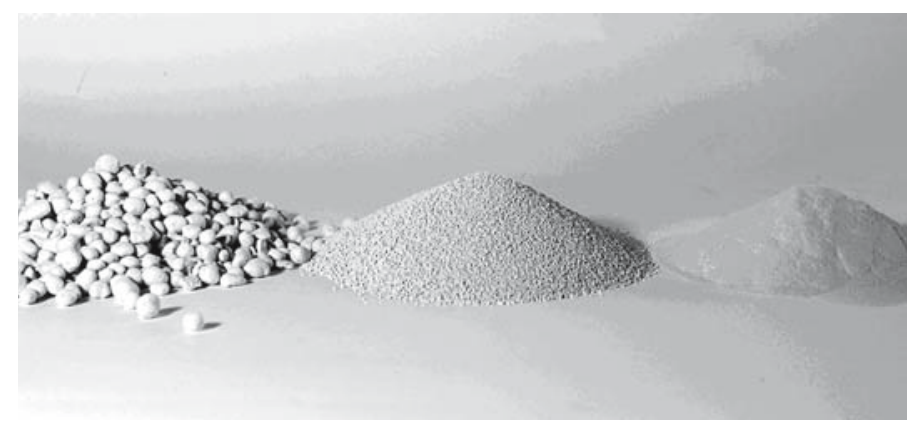

Figure 4. PORAVER granulated glass spheres 
At present time, three products are being distributed in Hungary: LIAVER, GEOFIL and PORAVER. For our purposes the PORAVER (Figure 4.) expanded glass spheres suited mostly, thus has been chosen for mixture.

\begin{tabular}{|c|c|c|c|c|c|c|c|c|c|c|c|}
\hline \multirow[b]{2}{*}{$\begin{array}{l}\text { Dimension, } \\
\mathrm{mm}\end{array}$} & \multicolumn{6}{|c|}{ PORAVER normal granulate } & \multicolumn{5}{|c|}{ Special granulate } \\
\hline & $\begin{array}{l}0,1- \\
0,3\end{array}$ & $\begin{array}{l}0,25- \\
0,5\end{array}$ & $\begin{array}{l}0,5- \\
1\end{array}$ & $1-2$ & $2-4$ & $4-8$ & $\begin{array}{l}0,04- \\
0125\end{array}$ & $\begin{array}{l}0,2- \\
0,7\end{array}$ & $\begin{array}{l}0,5- \\
1,25\end{array}$ & $2-3$ & $\begin{array}{l}8- \\
16\end{array}$ \\
\hline $\begin{array}{l}\text { Bulk } \\
\text { density, } \\
\mathrm{kg} / \mathrm{m}^{3}\end{array}$ & $\begin{array}{l}400 \\
\pm 60\end{array}$ & $\begin{array}{l}340 \\
\pm 30\end{array}$ & $\begin{array}{l}270 \\
\pm 30\end{array}$ & $\begin{array}{l}230 \\
\pm 30\end{array}$ & $\begin{array}{l}190 \\
\pm 20\end{array}$ & $\begin{array}{l}180 \\
\pm 20\end{array}$ & 530 & 530 & 260 & 260 & 140 \\
\hline $\begin{array}{l}\text { Cracking } \\
\text { force, } \mathrm{kN}\end{array}$ & 24 & 24 & 18 & 16 & 14 & 12 & 24 & 65 & 17 & 12 & 8 \\
\hline $\begin{array}{l}\text { Chemical } \\
\text { reaction } \\
(\mathrm{pH})\end{array}$ & \multicolumn{11}{|c|}{$9-12$} \\
\hline $\begin{array}{l}\text { Thermal } \\
\text { conductivity, } \\
\mathrm{W} / \mathrm{mK}\end{array}$ & 0,07 & 0,08 & 0,08 & 0,07 & 0,07 & 0,07 & 0,08 & 0,08 & 0,07 & 0,07 & 0.07 \\
\hline $\begin{array}{l}\text { Melting } \\
\text { point, }{ }^{\circ} \mathrm{C}\end{array}$ & \multicolumn{11}{|c|}{ cca. 700} \\
\hline $\begin{array}{l}\text { Lower } \\
\text { exacting } \\
\text { limit, } \mathrm{tf} \%\end{array}$ & \multicolumn{11}{|l|}{$\leq 15$} \\
\hline $\begin{array}{l}\text { Upper } \\
\text { exacting } \\
\text { limit, tf\% }\end{array}$ & \multicolumn{11}{|l|}{$\leq 10$} \\
\hline Colour & \multicolumn{11}{|c|}{ Creamy white } \\
\hline
\end{tabular}

Table 2. Technical data of PORAVER granulated glass spheres

\section{MIX DESIGN}

After the ideal aggregate was chosen, the required mix was planned. When designing lightweight concrete mix, specific principles should be considered. When working with normal concrete, the main features which are considered during planning are: expected strength, water/cement ratio, and quality and quantity of aggregates. In case of lightweight concrete the expected bulk density, the ratio of fine aggregates are also important factors.

The strength of lightweight concrete depends on the quality, quantity and type of applied cement, the water/cement ratio - which is usually a low rate, thus admixture is often used -, and the strength of aggregates. 
In consequence of the special technological task: creating a canoe of concrete, additional aspects were considered during designing the mix, for example: preventing the shrinkage and cracking, creating watertight material. These aspects were mentioned before.

On the grounds of the previously mentioned criteria, the final mix was designed. It was followed by testing and investigating the mixture, which resulted some slight changes in the mix. By these changes the authors attempted to improve consistency and homogeneity, which helped during the construction of the canoe.

The final mixture consisted of:

- EM I, 42,5 R

- Metakaolin (Metapor)

- Basalt powder

- Polypropylene fibres

- Fractions of granulated glass (Poraver)

- Admixture (Mapei Dynamon SR3)

- Water

- Water - fine aggregate ratio: 0,58

- Planned bulk density: $1.100 \mathrm{~kg} / \mathrm{m}^{3}$. [10]

The application of CEM I 42,5 R type cement was necessary because of the expected high early density. The competition announcement ensured a narrow time for design and creation, which resulted an intense work rate for the teams. Our time-management indicated, that on the day of competition our canoe going to reach only 14 days of solidification.

The size of metakaolin grains are smaller than cement, but bigger than silica powder. It is a highly reactive fine aggregate with suitable features for creating watertight concrete. Other advantages of using metakaolin[11]:

- Increases tensile and compressive strength,

- Increasing watertight performance

- Increases chemical resistance

- Increasing concrete lifespan

- Improving aesthetics and consistency

- Decreases shrinkage

The basalt powder were mixed in because of its small grain size to ensure the average low grain size of the compound.

The most important feature of fiber reinforced concretes are the high tensile and flexural strength. Moreover by using sufficient amount of fibre, the cracking caused by shrinkage is reduced. Polymer fibres show higher homogeneity than steel fibres, and they are reducing the tensile strain created by shrinkage in the material[12]. This effect was considered important, because a very thin wall is required for the canoe, meanwhile cracking should be minimized for the watertight effect. It is possible to create thin but strong concrete pieces by using these fibres. As a disadvantage, during building of the body we realized that the aesthetic of handmade surface was spoiled by the outhanging fibres. Although on the surface facing the formwork this problem did not occur. 
While using fibres proved to be advantageous, the consistency of fresh concrete decreased, therefore application of fluxing admixture became necessary in order to maintain the manageability of mixture. This admixture also allowed us to use less water (reducing water/cement ratio) while maintaining high consistency.

The Poraver granulated glass proved to be an ideal aggregate. The planned thickness of the wall $(10 \mathrm{~mm})$ required a $4 \mathrm{~mm}$ maximal size of the spheres.

The finalization of the mix was followed by test mixing (Figure 5.), creating of the specimen layer (Figure 6), and measuring tensile and compressive strengths (Figure 7.)
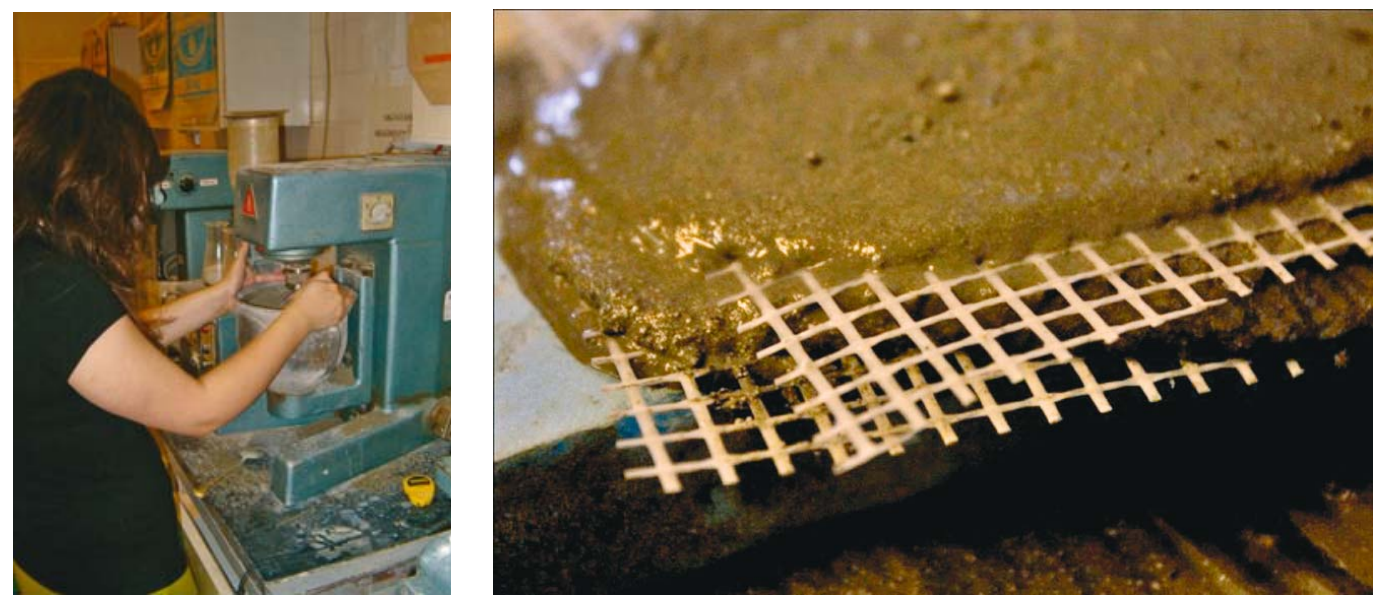

Figure 5. Small amount of test-mixture

Figure 6. Layers of body

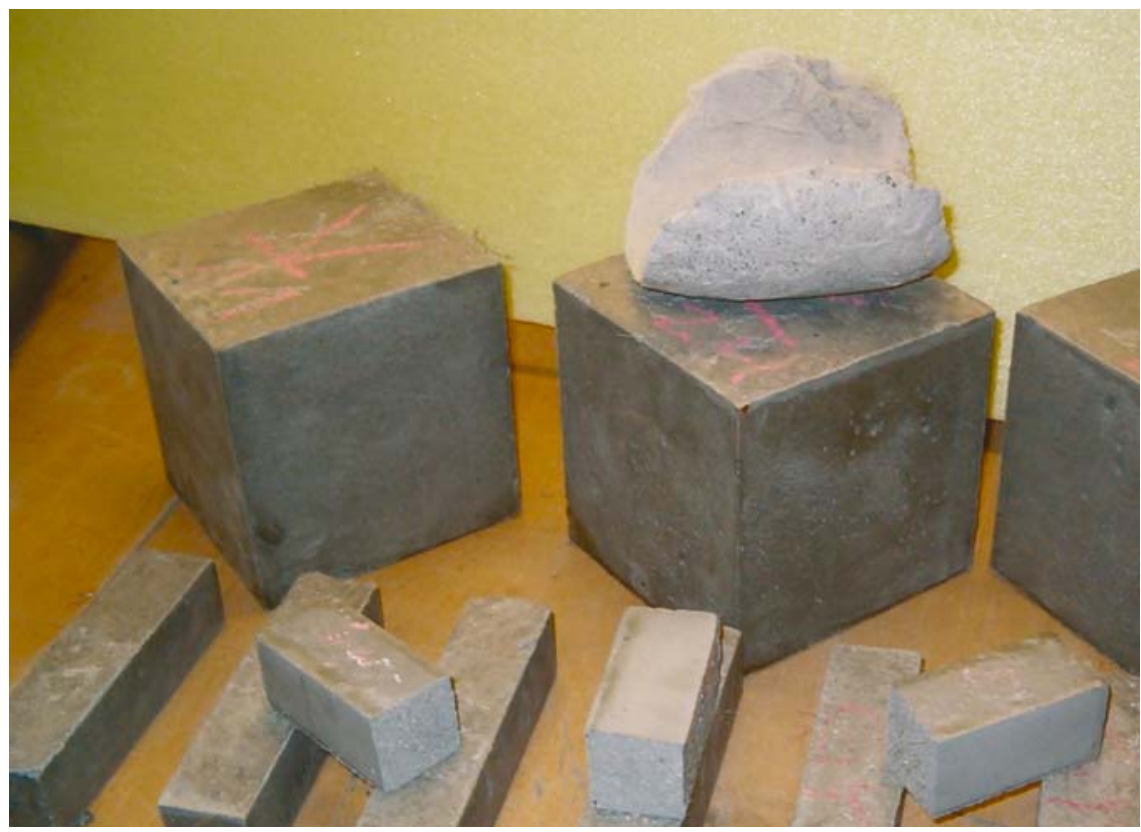

Figure 7. Test pieces of different mixtures 


\section{RESULTS OF INVESTIGATIONS}

The planned bulk density of the mixture was $1100 \mathrm{~kg} / \mathrm{m}^{3}$, which was successfully approached by the actual value: $1120 \mathrm{~kg} / \mathrm{m}^{3}$

The tensile-flexural strength of the hardened concrete is shown on Figure 8. The measurement was made by using a Tonitech type device. The compressive strength values are shown on the Figure 9. (made by Instron 2308 universal tensile-compression testing machine).

Note: the concrete canoe was 14 days old on the day of the competitions.

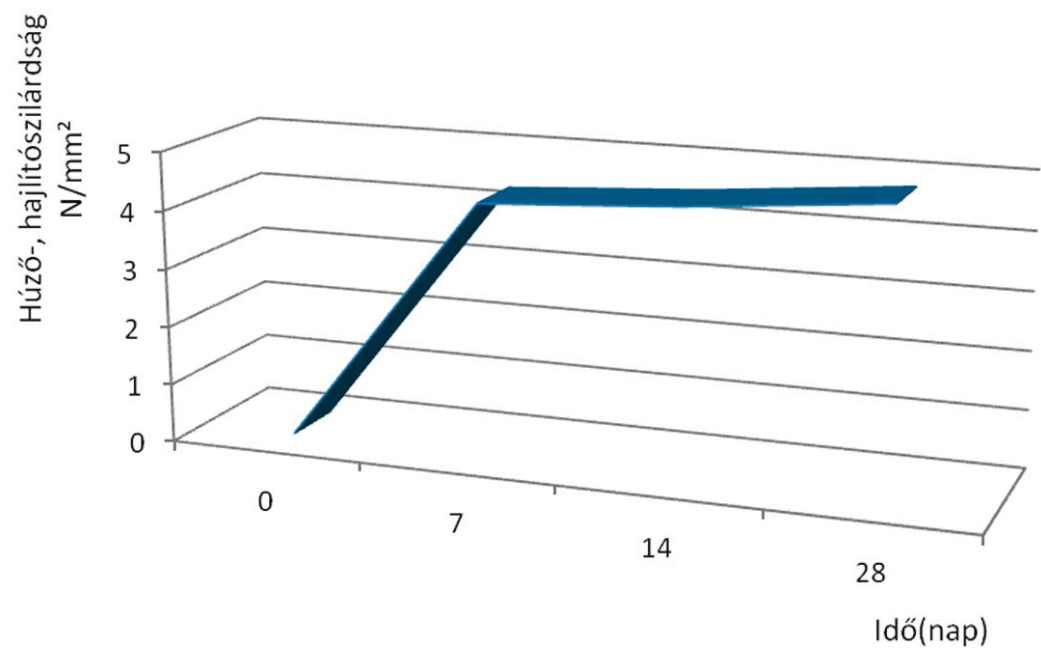

Figure 8. Values of tensile strength

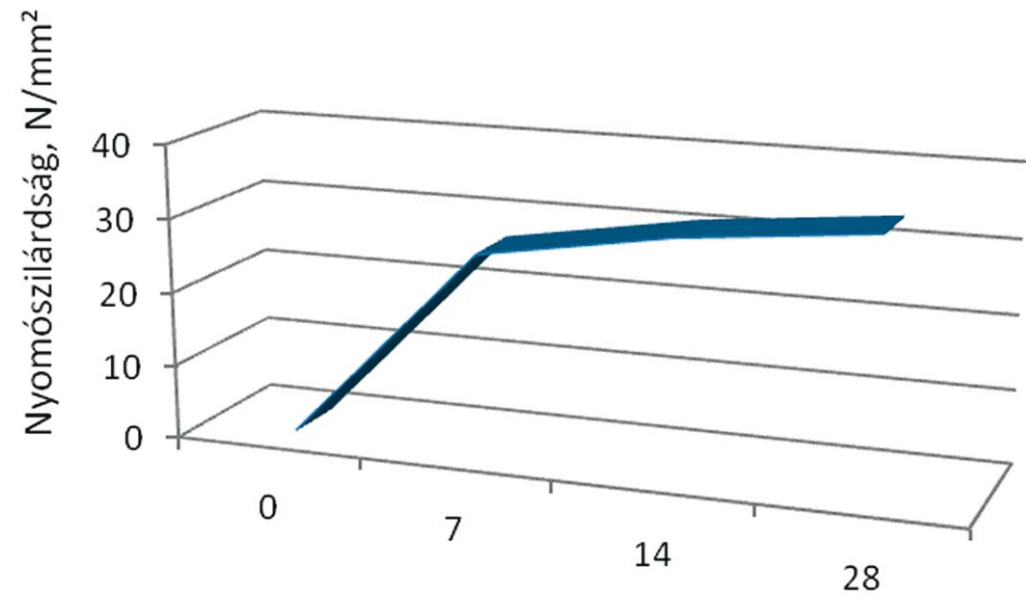

Figure 9. Values of compression strength 
The ripping strength was measured on $150 \mathrm{~mm}$ test cube: on the $14^{\text {th }}$ day was $45 \mathrm{kN}$. The tensile strength was measured on 40x40x160 mm test piece. Both cases the broken surface was surveyed (Figure 9., 10.).

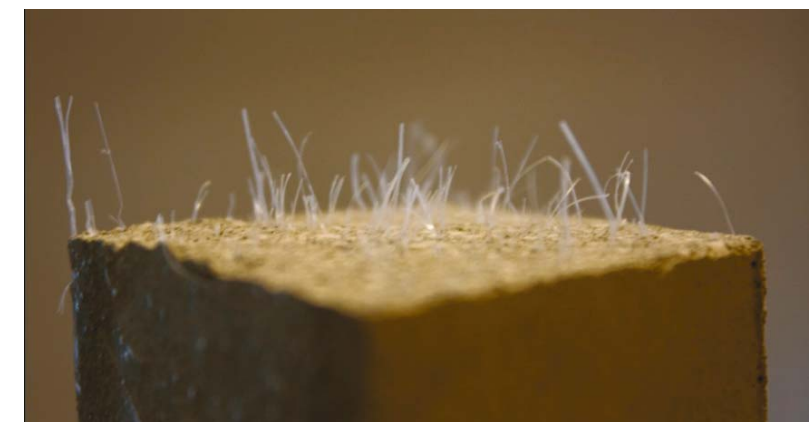

Figure 10. The broken surface of 40x40x160 mm test piece

\section{CONSTRUCTION TECHNOLOGY}

In line with elaborating the mix, the designing process of the body of canoe started. As first step, deciding the method of construction technology was required. During preliminary survey the authors reviewed possibilities, which helped choosing the best option.

The technology and method of creating the body is a crucial factor which influenced most of the following work, including the consistency of mixture.

\subsection{Designing the body of canoe}

Without any previous experience of concrete floating objects, the team decided to put safety forward while designing the body. Two different methods were possible for design: borrowing an actual plastic canoe, and use it as a formwork board, or creating the form as an individual design. The latter was chosen, and by three dimensional virtual modelling the ideal form was designed from which the required parts of formwork were easily shaped (Figure 11.)

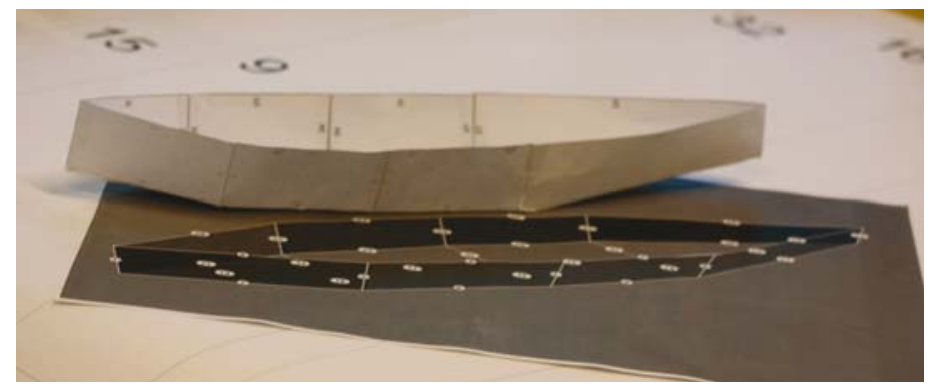

Figure 11. The model of the formwork 


\subsection{The formwork}

On the source of previous surveys two different methods of moulding could be chosen: one-layered formwork (inner or outer layer), or traditionally pouring the mixture in between two layers of formwork boards. Later it turned out, that all the competition teams had the same dilemma. One team tried to build by using traditional formwork-boards, but came up against various different difficulties, and the attempt failed. The Ybl-team chose an inner formwork, on which later built and stacked the layers of concrete by hand. Using a layered structure was required to strengthen the body.

After building the formwork (Figure 12.), the formwork was set together from polystyrene parts (Figure 13.). These parts were previously cut and shaped based on the virtual 3D design of the body. Joint gaps were filled with epoxy glue and the edges were shaped.

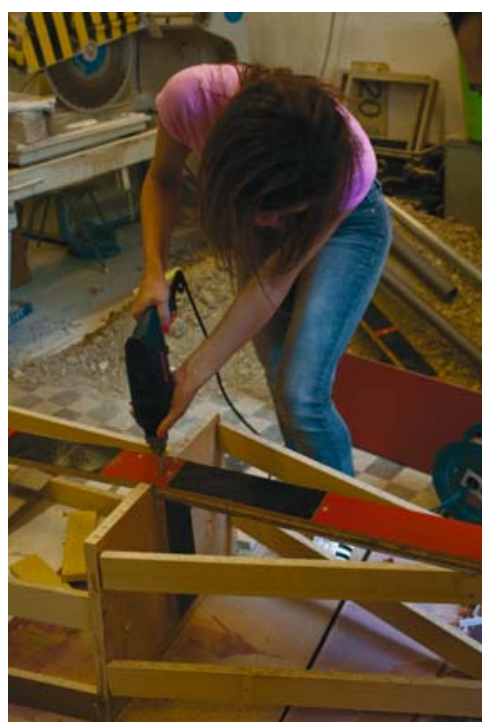

Figure 12. Frame of the formwork

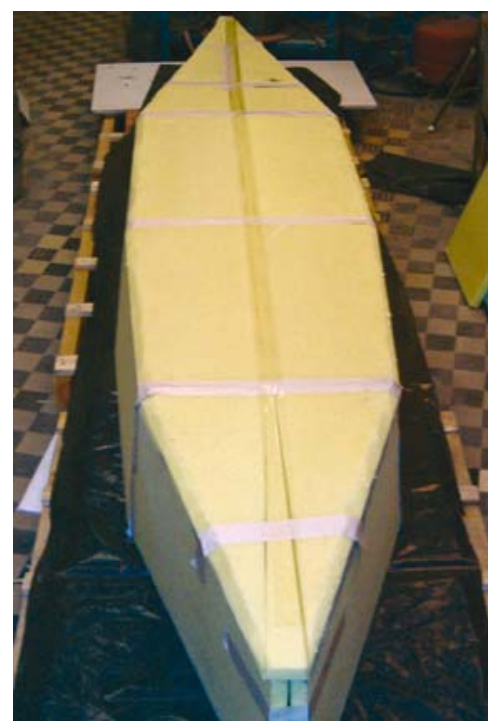

Figure 13. Extruded polystyrene formwork

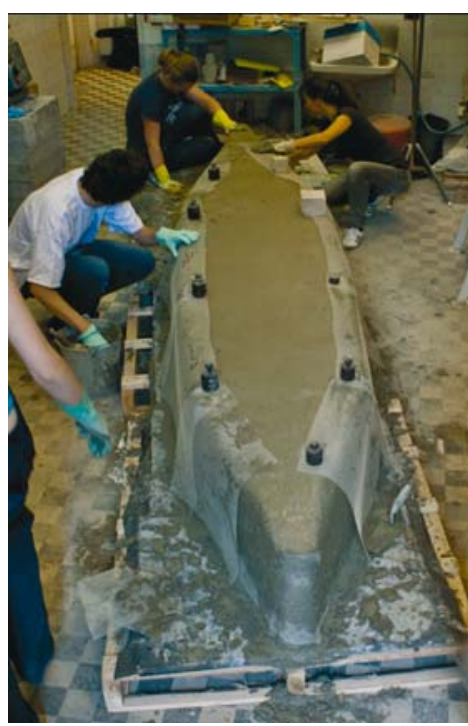

Figure 14. Different layers of the body

\section{THE REALIZATION}

The preliminary mix underwent a slight modification, for consistency correcting purposes. The required concrete quantity was not mixed all at once, rather bit by bit in smaller portions, while the other part of the zealous team continuously plastered the fresh concrete by hand onto the previously made formwork. The canoe was designed laminiform, therefore a fiberglass layer followed the first concrete layer. Totally the final body contains three layers of concrete and two layers of fiberglass - although the vertical wall of the body only measures $1,5-2 \mathrm{~cm}$, which indicates the skilfulness of the team (Figure 14.). 
For securing the continuous work, which was a prime necessity to avoid cracks, the fiberglass parts were shaped and prepared beforehand.

The quality of surface was also an important aspect, therefore the team had to pay attention not only to fit the layers, but meanwhile creating an aesthetic surface too (Figure 15.)

During construction came the idea of creating a concrete "YBL" logo to the body (Figure 16.). As a final touch, a thicker concrete layer was made on the spine of the body to strengthen the keel and increase stability.

During the next 14 days the body was wetted as a curing, meanwhile the team arranged the transportation and started the countdown for the competition - which was only 14 days ahead

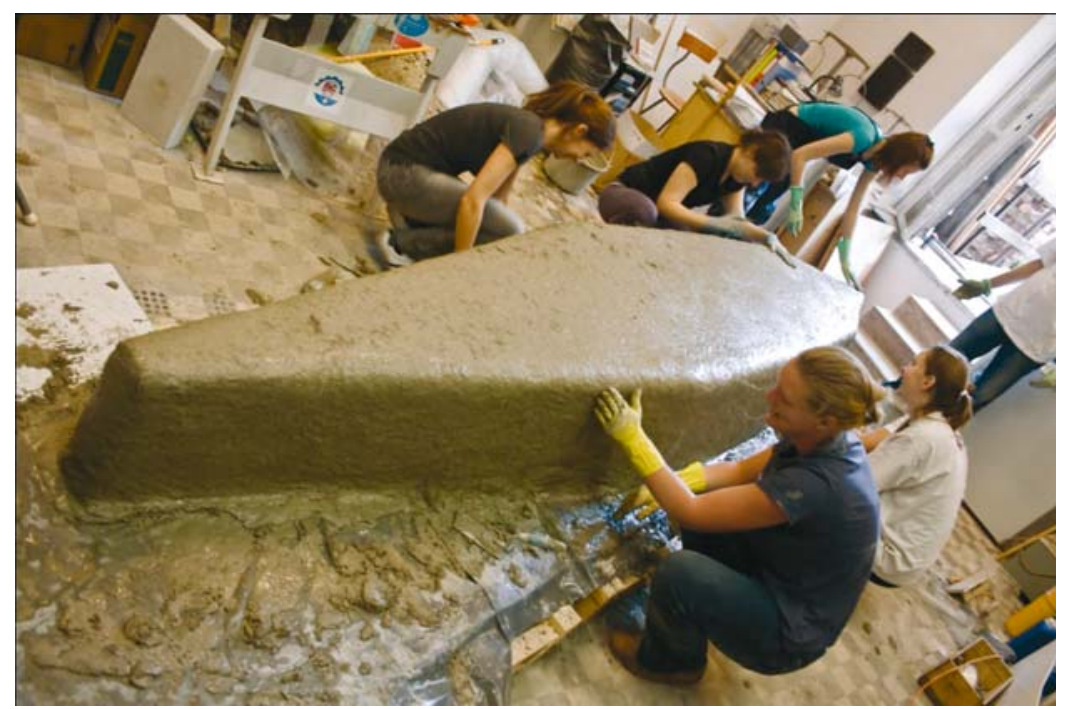

Figure 15. Last touches

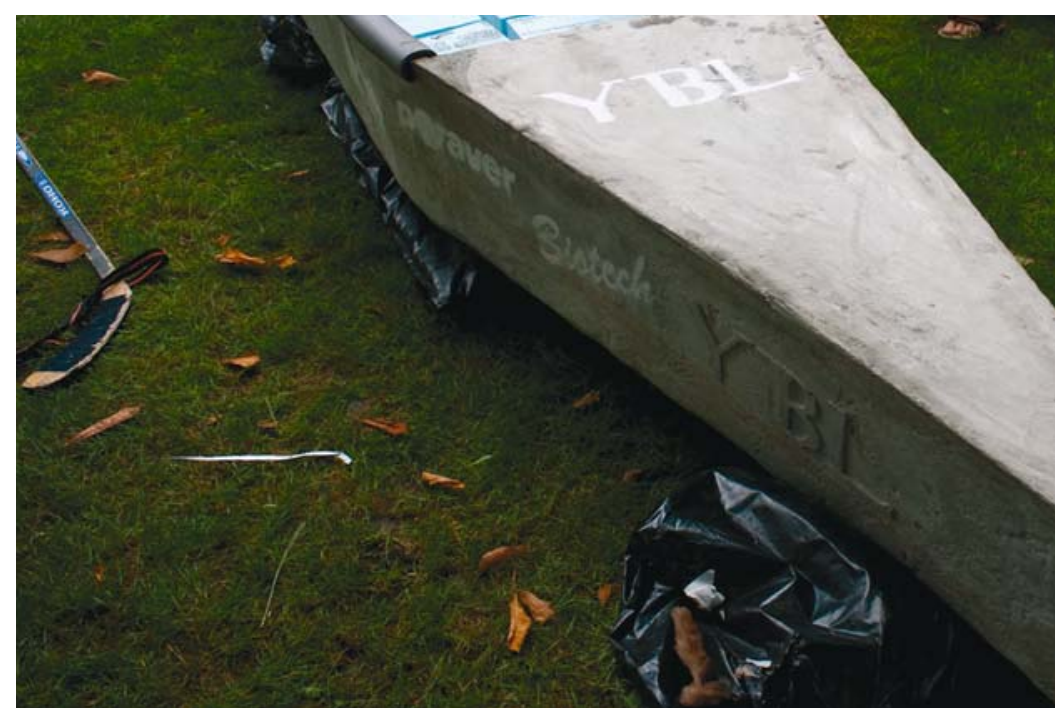

Figure 16. Logo made of concrete 


\section{THE DAY OF COMPETITION}

The competition was organized in Ráckeve (Figure 17.). The evaluation and the event contained three main parts: short oral presentation of the creating of concrete canoe, investigation and measurement of the canoes by the jury, and the actual canoe competition in the Danube. Previously most of the competitors attempted to keep their chosen technology a secret, and only presented it during oral presentation as part of the competition. The official measurement concluded that the mass of canoes were between 110-300 kg, the authors' canoe weighted the lightest: $110,2 \mathrm{~kg}$ (Figure 17.) The team of Ybl Miklós faculty (team name: Mission Imposs YBL) won a prize for fair competition and got the second place in competition between Universities.

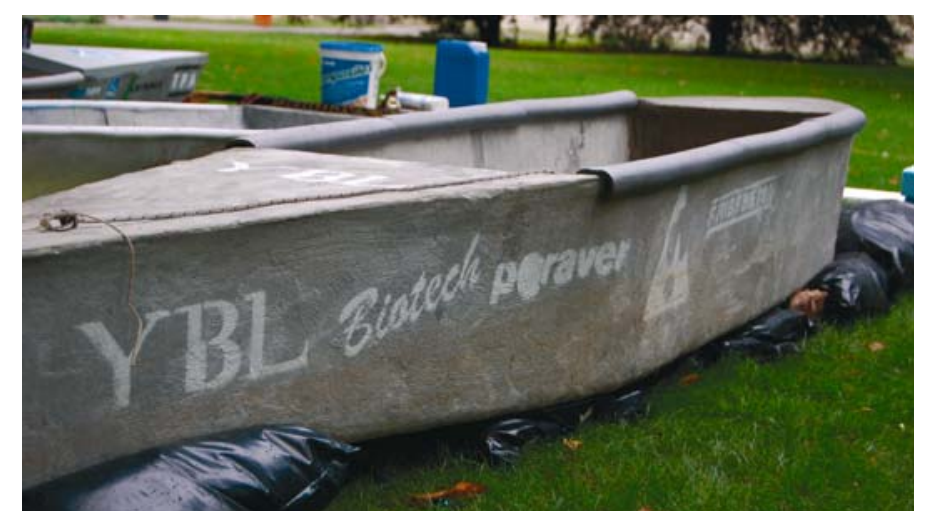

Figure 17. The finished concrete canoe on the day of competition

\section{CONCLUSIONS}

This paper contains information about the authors' preliminary investigation, designer and engineering work for creating a canoe for attending the I. Hungarian Concrete Canoe Competition (organized in 2012). The event was widely advertised in media, increasing the reputation of our University and Faculty.

In few words the authors successfully completed the task of creating a concrete canoe and competing with it, and the same time giving inspiration for the other competitors. As in 2012, the mass of canoes was measured between 110-300 kg - the lightest was the canoe of the $\mathrm{Ybl}$ - team -, in 2013, the competing canoes were measured between $60-130 \mathrm{~kg}$.

Further investigation aims to improve:

- decreasing water-cement ratio,

- optimizing the amount of admixture,

- replacing basalt powder,

- using silica powder and metakaolin in optimized amount,

- increasing tensile strength,

- decreasing thickness of the canoe

- improving hydrodynamic properties 


\section{REFERENCES:}

[1] Balázs Gy.: Beton és vasbeton I. Alapismeretek története Akadémiai Kiadó, Budapest, 1994

[2] Kari TDK híradó, 2012/2. SZIE-YMÉK, (szerk.: Leczovics P.), Budapest,

[3] http://nambal.egloos.com/1464274

[4] Leczovics P. - Polyák Á.: Gipszbeton szerkezetek szilárdságbecslö vizsgálatai - Technika Müszaki Szemle, Budapest, 2011/3 p.20-21.

[5] Takács M. - Sugár VikTóRia: Nagyteljesítményü öntömörödő betonok tulajdonságainak és alkalmazhatóságának vizsgálata ÉTE konferencia, Budapest, 2010.10.28.

[6] www.betonopus.hu

[7] Leczovics P. Egy korszerü adalékanyag: az üveggranulátum Technika Müszaki Szemle, 2013

[8] Balázs G.: Építőanyagok és kémia, Müszaki Könykiadó, 1984

[9] Leczovics P.: Extenzív zöldtetők hazai vizsgálatai Magyar Épitéstechnika, 2011/7-8 p.52-55.

[10] Sugár V., Leczovics P.: Miböl lesz a betonkenu? ÉTE konferencia, Budapest, 2012

[11] http://en.wikipedia.org/wiki/Metakaolin

[12] http://www.kera.hu/Data/csemegek/Acelszal,\%20m\%FBsz $\%$ E11\%20er\%F5s\%EDt\%E9s\%FB\%20betonok.pdf 